\title{
The potential of electricity generation from the major agricultural wastes in the Mekong Delta of Vietnam
}

\author{
Tiềm năng phát điện từ một số chất thải nông nghiệp chính ở đồng bằng sông Cửu long
}

\author{
NGUYEN Vo Chau Ngan ${ }^{1}$; NGUYEN Thi Thuy ${ }^{2}$; NGUYEN Le Phuong ${ }^{3}$ \\ ${ }^{1}$ College of Environment and Natural Resources, Can Tho University, 3-2 street, Can Tho city, Vietnam; ${ }^{2}$ Project on "Sustainable Biogas Production from \\ Waste Rice Straw", Can Tho University, 3-2 street, Can Tho city, Vietnam; ${ }^{3}$ Hau Giang Industrial Zones Authority, Hau Giang province, Vietnam
}

\section{Dedicated to Dr. Nguyen Van Be}

\begin{abstract}
Agricultural activities produce a large quantity of waste each year in the Mekong Delta. For example, appropriately 26.86 million tons of rice straw, 5.37 million tons of rice husks, 1.33 million tons of bagasse and 0.59 million tons of corn straw were produced in 2016. Despite such a huge quantity of agricultural waste, the waste has been rarely used effectively. Around $54.1-98.0 \%$ of rice straw is normally burnt on the field; only 20 - 50\% of rice husk is used for pellet or energy purposes; a few sugar-cane factories apply bagasse feeding to steam cookers, and a small quantity of corn straw is used as livestock feeding. If this biomass source is used for electricity generation, in theory, for the period of 2006 - 2020, it is estimated that this source can potentially generate 1203 million MWh/year from rice straw, 236 million $\mathrm{MWh} /$ year from rice husk, 45 million $\mathrm{MWh} /$ year from bagasse, and 40 million $\mathrm{MWh} /$ year from corn straw. Electricity generation of biomass source will not only solve the problem of environmental pollution caused by agricultural waste but also meet increasing energy demands for socio-economic development in this region.
\end{abstract}

\begin{abstract}
Hàng năm lượng chất thải phát sinh từ một số loại hình canh tác nông nghiệp chính ở ĐBSCL rất lớn. Chỉ tính riêng năm 2016 ghi nhận thải ra khoảng 26,86 triệu tấn rơm rạ; 5,37 triệu tấn vỏ trấu; 1,33 triệu tấn bã mía và 0,59 triệu tấn thân cây bắp. Lượng chất thải phát sinh lớn nhưng các biện pháp sử dụng những nguồn sinh khối này chưa đa dạng, rơm rạ phần lớn được người dân đốt trực tiếp ngay trên đồng ruộng chiếm 54,1 - 98,0\% Iượng rớm rạ thải ra; chỉ có khoảng 20 - 50\% lượng vỏ trấu được sử dụng; bã mía chỉ được một số nhà máy sử dụng để đốt cho lò hơii; một lượng nhỏ thân cây bắp được người dân sử dụng cho chăn nuôi. Nếu có thể tận dụng các nguồn sinh khối này để sản xuất điện thì tiềm năng lý thuyết ước tính từ năm 2005 đến 2020 của rơm rạ là 1203 triệu MWh/năm; vỏ trấu là 236 triệu MWh/năm; bã mía là 45 triệu MWh/năm; và thân cây bắp là 40 triệu MWh/năm. Sản xuất điện từ các nguồn sinh khối này không chỉ giải quyết lượng phế phẩm nông nghiệp phát sinh, giảm thiểu ô nhiễm môi trường mà còn có thể tạo ra nguồn điện cung cấp cho nhu cầu phát triển của vùng.
\end{abstract}

Keywords: corn straw, renewable energy, rice husk, rice straw, sugar-cane bagasse

\section{Background}

Vietnam is a developing country with an increasing demand for energy. In the past 10 years, there was a fastrising demand for energy (10\%) and electricity (14.5\%) (COGEN 3 - EC-ASEAN COGEN Programme, 2003). It is estimated that the demand for electricity and energy will be 6 and 4 times higher in the next 20 years (Prime Minister, 2012). Due to limited reserves, traditional energy sources are gradually depleted while the demand is increasing. In Vietnam, it is estimated that the energy sector will be vulnerable in the near future due to its strong dependence on fossil-based energy. The ratio of fossil oil within total primary energy consumption is expected to increase from $42 \%$ in 2002 to $69 \%$ in 2030 while renewable energy ratio is decreasing from $58 \%$ to $22 \%$ at the same period due to a total increase in energy generation (Nguyen Ngoc Hoang, 2015). As fossil energy exploitation and application cause environmental issues, development of renewable energies could be a key point to optimize the use of fossil energy to limit environmental pollution during the exploitation and use of fossil energy.

As an agricultural nation, Vietnam has a high potential for renewable energy, especially biomass consisting of agricultural by-products or residues. Electric production from biomass sources could be an ideal supplement to deal with electricity shortages, helping to diversify energy sources and to ensure national energy security. 
The Mekong Delta (MD), known as a "rice bowl", is one of two main agricultural production areas in Vietnam. As a result, every year a huge quantity of agricultural residues including rice straw, rice husk, bagasse, corn stalk, etc. is discharged to open environment. In particular, rice straw produced in the MD was 26.2 million tons in 2012 (Nguyen \& Tran, 2015). However, these types of waste are not used in a sustainable and effective way while several studies reported that these wastes could be used as input materials to produce electricity (Jenjariyakosoln, 2014; Suramaythangkoor, 2010). Therefore, this study was aimed to evaluate the current status and possibility of application of agricultural residues (such as rice straw, rice husk, bagasse, and corn stalk) to generate electricity in the MD to help the region make use of the residues economically and friendly to the environment.

\section{Methodology}

\subsection{Data collection}

For a better understanding of the quantities of biomass resources, production numbers from agriculture were gathered from the National Yearly Statistical Book of Vietnam.

\subsection{Potential of agricultural residues}

The theoretical potential of agricultural residues in the MD was estimated on the basis of the yearly statistic yearbook data for agricultural production, residue-to-production ratio:

$$
A R=A P \times R A P
$$

where:

AR: agricultural residues (ton/year)

AP: agriculture production (ton/year)

RAP: ratio of residue/plant production (ton/ton)

Table 1. RAP value of studied plants

\begin{tabular}{llc} 
No. & RAP & Value (ton/ton) \\
\hline 1 & Straw/rice & 1.0 \\
2 & Husk/rice & 0.2 \\
3 & Bagasse/sugar-cane & 0.3 \\
4 & Corn stalk/corn & 2.5 \\
(Source: Leinonen \& Nguyen, 2013)
\end{tabular}

\subsection{Potential for electricity production}

The theoretical potential for electricity production from agricultural residue:

$$
E=A R \times Q
$$

where:

E: potentially produced electricity (MWh/year)

AR: agricultural residue (ton/year)

$\mathrm{Q}$ : calorific value of material $(\mathrm{kWh} / \mathrm{kg})$
Table 2. Thermogenetic of agricultural residues

\begin{tabular}{llc} 
No. & Residue from & Caloric value $(\mathrm{kWh} / \mathrm{kg})$ \\
\hline 1 & Rice straw & $3.0-3.5$ \\
2 & Rice husk & $3.0-3.4$ \\
3 & Bagasse & 2.1 \\
4 & Corn stalk & $4.6-4.7$
\end{tabular}

(Source: Barz, 2014)

\section{Results and discussions}

\subsection{Rice straw}

\subsubsection{The current status of rice straw usage}

The rice production area in the MD is approximately 4.4 million hectares ( $55 \%$ of the national area), making the MD the biggest rice cultivation region in the nation with 24.3 million tons of rice in 2013 (GSO, 2016). Based on conditions such as rice variation, harvest methodology, soil properties, etc., it can be assumed that rice straw discharge on the field is equal to the quantity of rice production (ratio of 1 : 1) (Leinonen \& Nguyen, 2013). Although the amount of rice straw is increasing each year and therewith the increase in paddy rice, the traditional usage of rice straw decreases.

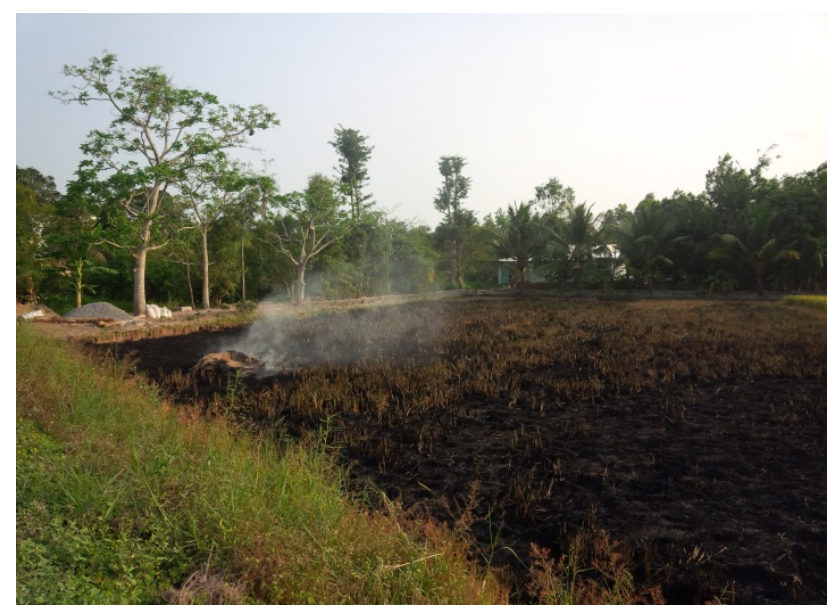

Figure 1. Rice straw burning causing pollution gases

In the past, rice straw was used for domestic cooking, but improved living conditions have ended this practice. At the moment, part of rice straw is utilized for mushroom cultivation, vegetable planting, cattle feed, pig bedding, etc. According to Nguyen \& Tran (2015), a previous survey on rice straw usage at 400 rice farming households in the $\mathrm{MD}$ revealed that the most popular rice straw treatment is on-field burning with 54.1 to $98.0 \%$ of the surveyed households, and burying in the field of 6.7 to $26.1 \%$ (different values due to different season of the year) (Table 3). These straw treatment methods can bring no benefits to local farmers but can cause environmental pollution. Burning 1 ton of straw could emit $36.32 \mathrm{~kg}$ of $\mathrm{CO}, 4.54 \mathrm{~kg}$ of hydrocarbon, $3.18 \mathrm{~kg}$ of ash, and $56 \mathrm{~kg}$ of $\mathrm{CO}_{2}$ (Ngo \& Duong, 2005); these gases are harmful to people and cause greenhouse effects. 
Table 3. The straw treatment methods in the MD

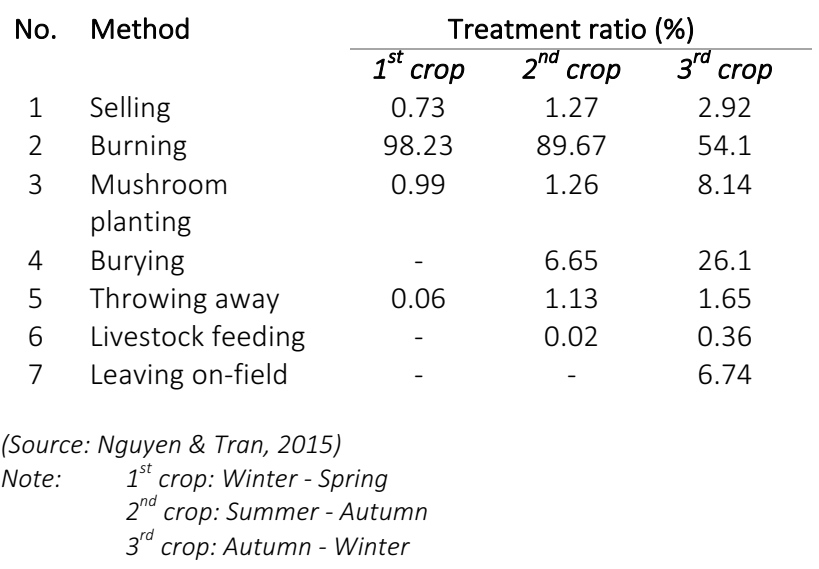

Burying rice straw on-field after harvesting creates an anaerobic fermentation condition in the soil profile, causing rice plants to die due to damage of their roots by organic poisoning, and rice production decrease (Nguyen Thanh Hoi, 2008). A few uses for rice straw that bring profit to farmers are mushroom cultivation (0.99-8.14\%) and livestock husbandry (0.02 - 0.36\%). However, these applications are used only at household scale.

\subsubsection{Theoretical potential of electric power from rice straw}

The use of straw as an energy source is realized in several countries. In Europe, Denmark was the first one that developed power plants using agricultural wastes, and the first electricity plant using straw as input material was built in 1989. In 2002, other large-scale electricity plants were built at Ely - UK (38 MW) and Sangüesa - Spain (25 MW) (Suramaythangkoor \& Gheewala, 2010). In Asia, since 1992 there has been a $10 \mathrm{MW}$ biomass electricity plant with fluidized bed technology built at Punjab - India, but due to technical problems at the feeding unit, the plant could not operate satisfyingly. In 2004, this plant was recovered by replacing a new feeding unit which could apply straw, rice husk, sawdust, etc. as raw materials. In China, two biomass electricity plants were constructed in 2007 - one of $25 \mathrm{MW}$ in Jiangsu city and the other of $12 \mathrm{MW}$ at Hebei city (Suramaythangkoor \& Gheewala, 2010).

According to the Vietnam Master Plan on agricultural production development to 2020, vision to 2030 (Prime Minister, 2012) which was signed by the Prime Minister on February $2^{\text {nd }} 2012$, the growth rate of agriculture, seafood and forestry production value is from 4.3 to $4.7 \%$ per year. By such an estimated growth rate of rice production, annual rice straw discharge will increase greatly. Figure 2 indicates that the theoretical potential of electricity production from rice straw in the MD from 2006 to 2020 is significant. In the MD, with a huge quantity of straw discharged annually, it could be a great opportunity to produce electricity from this residue.

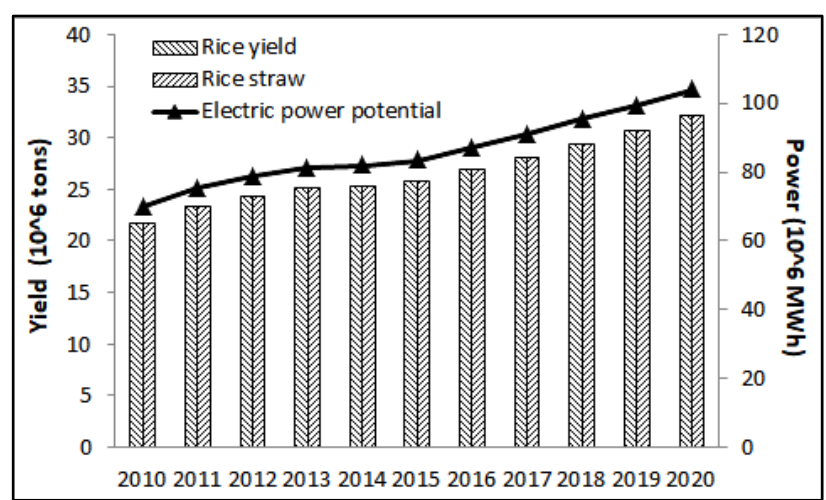

Figure 2. Theoretical potential of rice straw for electricity production in the MD

\subsection{Rice husk}

\subsubsection{The current status of rice husks}

Rice husks (or rice hulls) are the hard protecting coverings of grains of rice which will be separated out of rice seed in a rubbing process. After the rubbing process, rice husks in the form of dry material and small pieces detach themselves, break up and become soft and easy for transportation. As it is hard for a micro-organism to degrade rice husks due to their high macromolecule fibre, storage and preservation of rice husks are simple. In addition, rice husks can be used as building material, fertilizer, insulation material, or fuel.

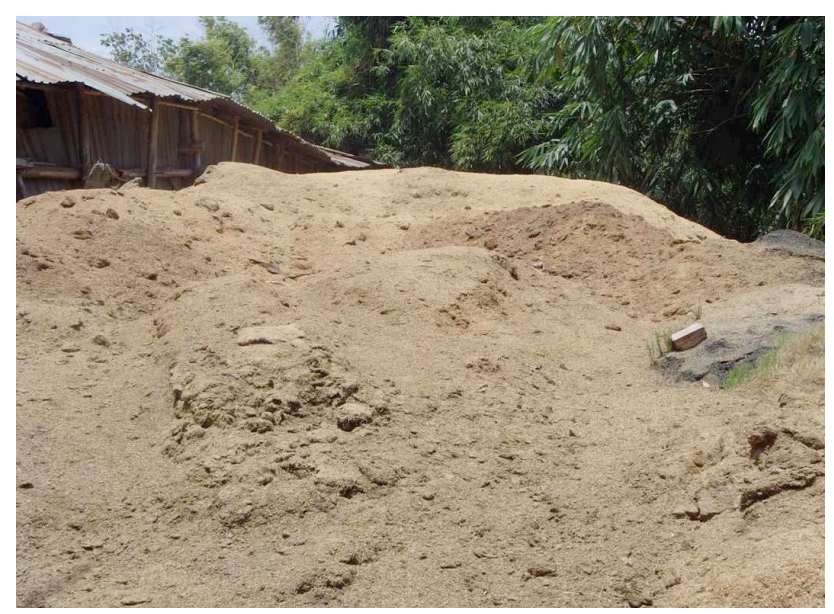

Figure 3. Rice husks residue in rice mills

It is estimated that the ratio of rice husks to rice seeds is 0.2 (Leinonen \& Nguyen, 2013), the annual discharge of rice husks is more than 4 million tons in the MD. Though a huge amount of rice husk is available, the use of this residue is limited and less efficient. Around $20 \%$ of rice husk was put to use for households' activities such as cooking, lime baking, or brick baking in the MD (Nguyen Van Song, 2009). Another survey at 108 rice processing plants located at 14 districts in Can Tho, An Giang, Kien Giang, Hau Giang and Soc Trang displayed that around 50\% of rice husks was sold for domestic cooking fuel and fertilizer purposes, but around 232.000 tons of rice husks remained un-used (Tan Hien, 2010). The quantity of rice 
husk in the MD region changes during the year. Normally, the peak season of paddy milling is from February until June. After this period the paddy milling capacity reduces slowly until October. In November, December and January nearly all rice mills operate periodically or stop their operation. Therefore, the supply of rice is not enough for rice husk power plants in these months. As such, storing rice husk is necessary (Leinonen \& Nguyen, 2013).

\subsubsection{Theoretical potential of electricity production from rice husk}

As paddy rice production increases annually, the quantity of rice husk increases accordingly. It is easy to collect rice husks when this residue is generated at rice processing factories. Rice husks could be used as raw material to produce electricity (Orkide \& Jyrki, 2012; Shafiea et al., 2012). There is an opportunity to use this huge source of material for electricity generation that serves for the development demand of the MD.

According to the report on development feasibility of biomass power plants (Nguyen Van Song, 2009), the yearly available rice husks of $1.4-1.5$ million tons in the MD could be used for 5 rice husk power plants with the capacity of $11 \mathrm{MW}$ for each plant. Application of rice husks for electricity generation can not only solve a huge quantity of agricultural residue that causes pollution at rice growing locations (An Giang, Can Tho, Dong Thap, Long An, and Tien Giang) but also produces a green energy source for clean development mechanism.

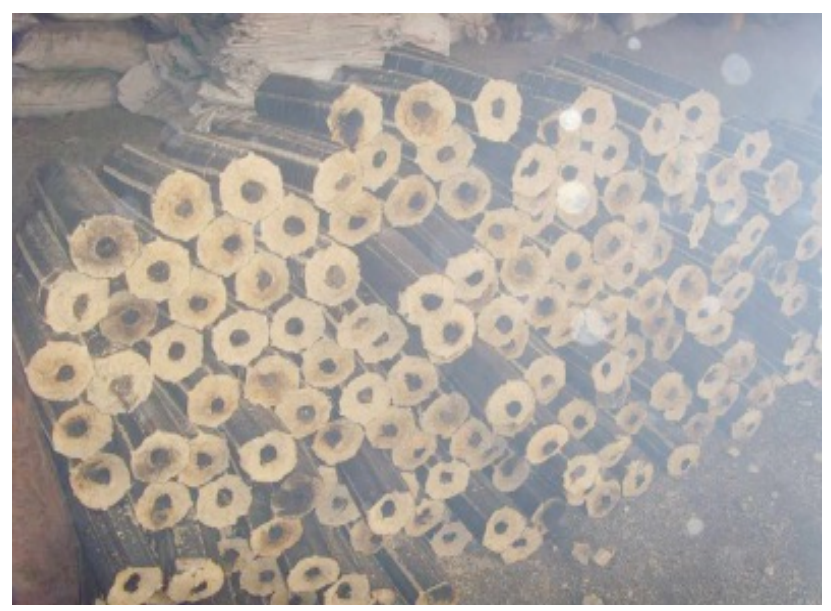

Figure 4. Rice husk pellets for fuel

In the MD there is one $50 \mathrm{~kW}$ rice husk fired co-generation system that has been installed as a demonstration plant at the Food Milling and Processing Enterprise No. 2 in Long An province. The project has been implemented in 1999 with financial support from the Australian government. The co-generation system consists of a 2.5 ton per hour fluidized bed boiler, a $50 \mathrm{~kW}$ steam turbo-generator, a heat exchanger and three paddy dryers. Another project applying rice husk is made by Dinh Hai Cogen Joint Stock Company to build the first steam power plant at Tra Noc Industrial Park (in Can Tho city) in 2006. The power plant produces steam of 25 tons of rice husk per hour $(6000$ hours per year) that is used by surrounding industrial companies. The annual consumption of rice husks in this power plant is 37,500 tons which is equivalent to 150,000 MWh of electricity. The target of the company is to build a turbine of $7 \mathrm{MWe}$ in the future. Nevertheless, both of the plants stopped operation because of low economic efficiency (Leinonen \& Nguyen, 2013).

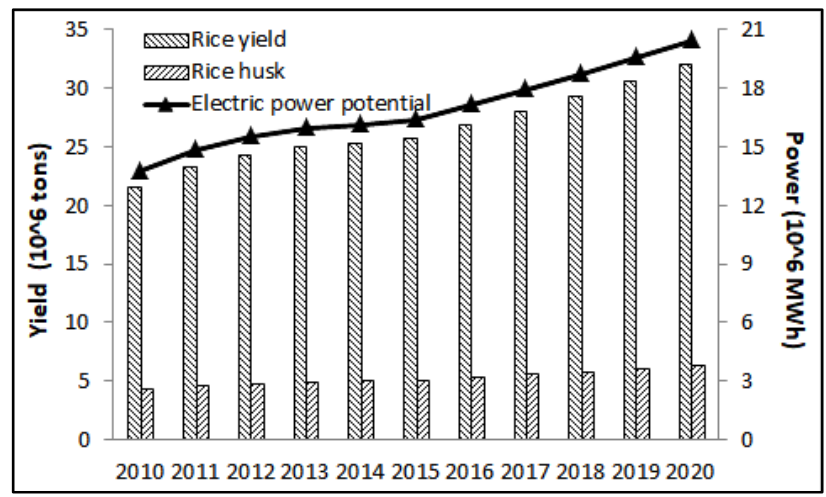

Figure 5. Theoretical potential of rice husks for electricity production in the MD

\subsection{Bagasse}

\subsubsection{Current status of bagasse at the MD}

Beside rice straw and rice husks, the most available biomass in the MD, bagasse is another huge source for energy production. Although sugarcane is growing acreage in the MD accounting for around $16 \%$ of the total national area, the average cane yield of 86 tonnes per hectare in this region is the highest in the country (Nhan Pham, 2014). The sugar industry has achieved a certain development that basically meets the domestic demand; and more importantly, created millions of jobs.

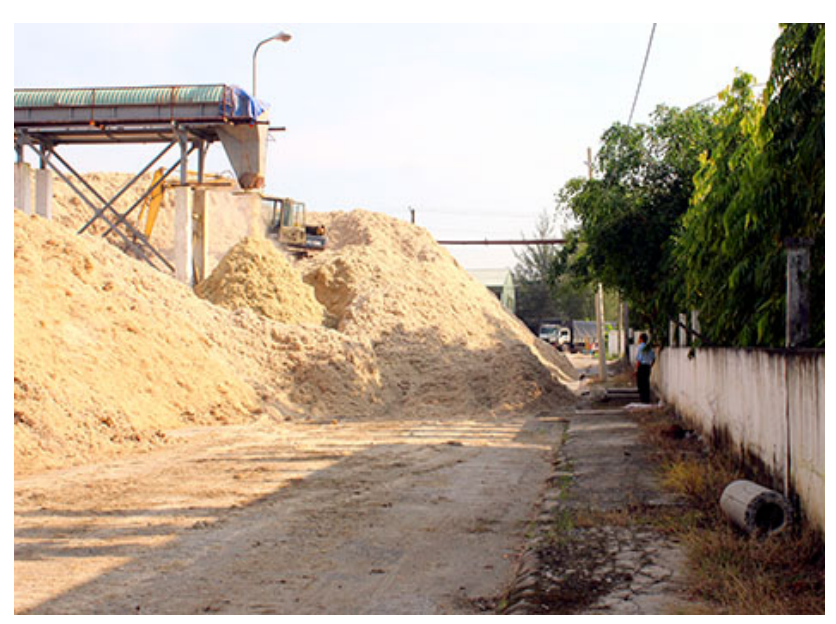

Figure 6. Bagasse from Vi Thanh Sugarcane Company (Source: Gia Nguyen)

With a bagasse-to-sugarcane ratio of 30\% (Leinonen \& Nguyen, 2013), the amount of bagasse created is considerably high. By the combination of heat and power (CHP), sugar mills apply bagasse to run steam boilers and supply electricity and heat for their own use. Since the 
heating value of bagasse is $2,340 \mathrm{kcal} / \mathrm{kg}$, it is estimated that around $80 \%$ of bagasse is applied for the required steam and heating from each sugar mill (Nguyen Minh Tung, 2009). The remaining part could be used for livestock feeding or simply released into open spaces, especially into a water body and this causes pollutions to local residential areas.

In 2013, the total installed power capacity of the CHP plants was about $150 \mathrm{MW}$ of electricity (Leinonen \& Nguyen, 2013). On March $24^{\text {th }} 2014$, the Prime Minister approved Decision No. 24/2014/QĐ-TTg on supporting the development of biomass power projects in Vietnam. EVN will purchase all electricity which is generated from biomass power plants with a price of 1,220 VND/kWh US 5.8 cents/kWh (excluding VAT, adjusting due to fluctuations in the exchange rate of VND/USD). As a result, in the crop year of 2015 - 2016, the designed power capacity of $\mathrm{CHP}$ plants was adjusted to $362 \mathrm{MW}$ electricity, and this value could increase up to $457 \mathrm{MW}$ electricity in the crop year of 2016 - 2017 (TTXVN/ VIETNAM ${ }^{+}, 2016$ ).

\subsubsection{Theoretical potential of electricity production from bagasse}

The theoretical potential of electricity produced from bagasse increases each year due to the increase in sugar production (Figure 7). The combustion of bagasse in power plants not only produces steam and heating serving for sugar mills themselves but also limits environmental pollution. The heating of one ton of bagasse with $50 \%$ moisture content is equal to 0.213 ton of raw oil, and the use of one ton of bagasse to produce electricity could reduce 0.55 ton of $\mathrm{CO}_{2}$ emission (Nguyen Van Loc, 2014). Besides that, the surplus electricity could be connected to the grid that brings more financial benefits to sugar enterprises.

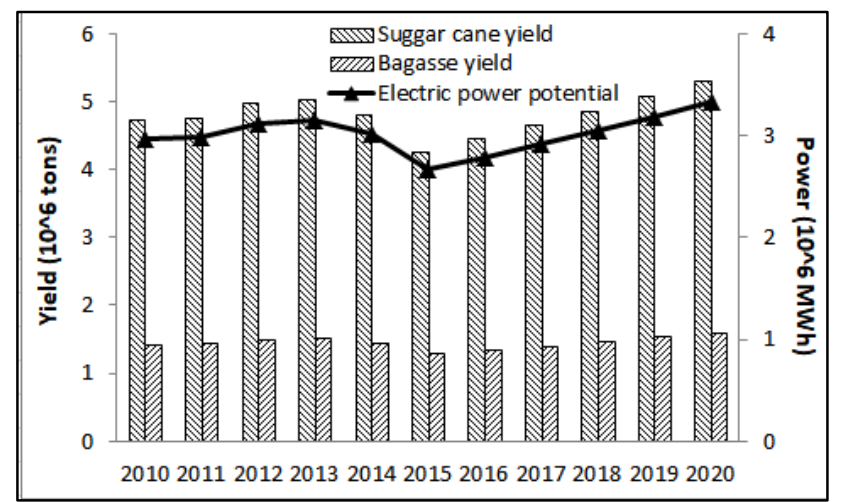

Figure 7. Theoretical potential of bagasse for electricity production in the MD

Leinonen \& Nguyen (2013) introduced a good example of applying bagasse to produce steam. Ben Tre Sugar Mill started its operation in 1998 with its average capacity of 2,000 tons of sugar cane per day. This sugar mill is in operation for 7 months (200 days) from October to April per year. The amount of bagasse production is about 84,000 tons $(176,000 \mathrm{MWh}$ or $635,000 \mathrm{GJ})$ per year. The power plant of the company consists of two boilers, and bagasse as the by-product of the sugar mill is used as fuel in the power plant. Each boiler produces 20 tons of steam per hour. The pressure of the steam is 26.5 bars, and the temperature is $400^{\circ} \mathrm{C}$. The steam is used for electricity production in a backpressure turbine and generator. After the turbine, the low-pressure steam is used for sugar processing. The electricity production capacity of both turbines is $1.5 \mathrm{MW}$. The sugar mill sells part of the surplus electricity $(0.2 \mathrm{MW})$ to its neighbouring company. The bagasse consumption of each boiler is $12-15$ tons per hour, so the total fuel consumption of the two boilers is about 76,000 tons of bagasse (160,000 MWh, 576,000 GJ) per year. This means that each boiler uses about 38,000 tons of bagasse. The surplus of bagasse (8,000 tons) in the sugar mill is used for pellet production.

\subsection{Corn stalk}

\subsubsection{Current status of corn stalk in the MD}

Corn is the second largest annual crop in Viet Nam after rice in terms of cultivated area. However, in the MD, the production-consumption of corn is not as popular as in the mountainous regions with poor soil fertility. Indeed, the corn harvest area in the MD only reached 34,900 ha in 2005 , after 10 years the harvest area slightly increases to 38.100 ha. Thus, corn production in the MD was around 225.000 tons in 2015.

As the corn stalk/corn grain ratio is 2.5 (Leinonen \& Nguyen, 2013), the corn stalk discharged on-field was estimated to be around 560,000 tons in 2015. This biomass could be used for livestock feeding, but this practice is not popular in the MD as local farmers normally raise livestock at small scale. According to a study from NL Agency (2012), around $18 \%$ of this residue is used for animal feed. Hence a large portion of corn stalk (82\%) is usually burned onfield, causing air pollution and greenhouse gas emission. Corn stalk is largely available in the MD and could potentially be used for electricity generation, but currently, it is used ineffectively.

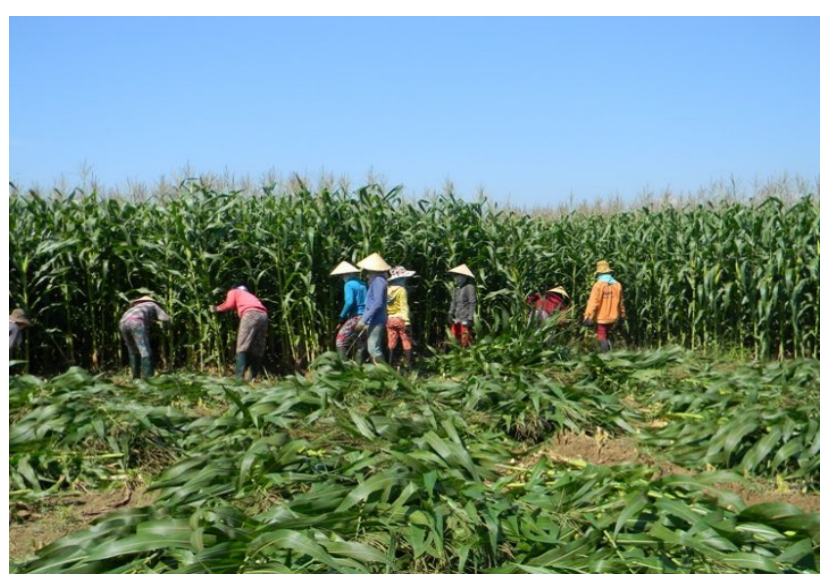

Figure 8. Corn stalk left on the field after corn harvest

(Source: Phan Thanh Son) 


\subsubsection{Theoretical potential of electricity production from corn stalk}

Figure 9 presents the annual corn yields and corn stalk production in the MD. Using corn stalk for power generation could reduce pollution and produce energy in the MD. Potential producing electricity from corn stalk can contribute from $2.7 \times 10^{6}$ to $2.9 \times 10^{6} \mathrm{MWh}$ electricity to the grid for not only the MD but also for the nation.

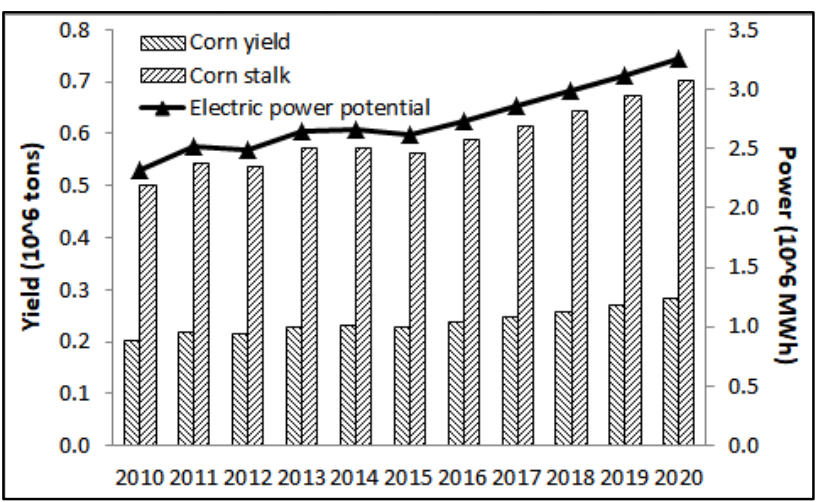

Figure 9. Theory potential of corn stalk for electricity production in the MD

\subsection{Discussions}

The MD discharges crop residues in a large quantity yearly. Based on the available sources, the mentioned residues can be classified into two categories - (i) the agricultural residues including rice straw and corn stalk, and (ii) agroindustrial residues including rice husk and bagasse. To produce electricity power from these residues, there are conversion technologies to be applied such as torrefaction, combustion, gasification, briquettes, aerobic (co)digestion, anaerobic (co)digestion, pyrolysis, etc. From a previous study by NL Agency (2012), only combustion method could be applied for all residues.

Table 4. Different conversion technologies

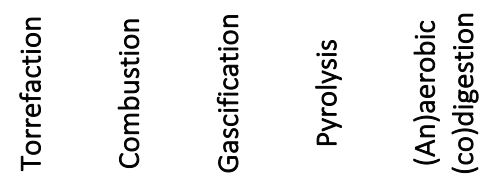

\begin{tabular}{lccccc}
\hline Rice straw & $?$ & $x$ & $?$ & & $?$ \\
Rice husk & $x$ & $x$ & & $x$ & $x$ \\
Sugar cane bagasse & & $x$ & $x$ & $x$ & $x$ \\
Corn stalk & $x$ & $x$ & $x$ & $x$ & \\
(Source: NL Agency, 2012) & & & &
\end{tabular}

Table 5 showed the average percentage of the potential of electric power production from the four major biomass sources in the MD.

Table 5. Average percentage of the potential of electric power production from various biomass sources

\begin{tabular}{|c|c|c|c|c|c|c|c|c|}
\hline \multirow[b]{2}{*}{ Year } & \multicolumn{2}{|c|}{ Rice straw (\%) } & \multicolumn{2}{|c|}{ Rice husk (\%) } & \multicolumn{2}{|c|}{ Bagasse (\%) } & \multicolumn{2}{|c|}{ Corn stalk (\%) } \\
\hline & Yield & Power & Yield & Power & Yield & Power & Yield & Power \\
\hline 2010 & 77.60 & 78.59 & 15.52 & 15.48 & 5.09 & 3.33 & 1.80 & 2.60 \\
\hline 2011 & 77.85 & 78.75 & 15.57 & 15.51 & 4.77 & 3.12 & 1.81 & 2.63 \\
\hline 2012 & 77.93 & 78.87 & 15.59 & 15.53 & 4.77 & 3.12 & 1.71 & 2.48 \\
\hline 2013 & 77.95 & 78.84 & 15.59 & 15.53 & 4.68 & 3.06 & 1.78 & 2.57 \\
\hline 2014 & 78.16 & 78.99 & 15.63 & 15.55 & 4.44 & 2.90 & 1.77 & 2.56 \\
\hline 2015 & 78.65 & 79.35 & 15.73 & 15.63 & 3.89 & 2.54 & 1.72 & 2.48 \\
\hline 2016 & 78.65 & 79.35 & 15.73 & 15.63 & 3.89 & 2.54 & 1.72 & 2.48 \\
\hline 2017 & 78.65 & 79.35 & 15.73 & 15.63 & 3.89 & 2.54 & 1.72 & 2.48 \\
\hline 2018 & 78.65 & 79.35 & 15.73 & 15.63 & 3.89 & 2.54 & 1.72 & 2.48 \\
\hline 2019 & 78.65 & 79.35 & 15.73 & 15.63 & 3.89 & 2.54 & 1.72 & 2.48 \\
\hline 2020 & 78.65 & 79.35 & 15.73 & 15.63 & 3.89 & 2.54 & 1.72 & 2.48 \\
\hline
\end{tabular}

Among the biomass sources mentioned above, around $75 \%$ of total rice straw is available for energy production (Nguyen \& Tran, 2015), but it is normally left on the field since it is inconvenient for farmers to collect the rice straw. In addition, around $80 \%$ of total rice husks and bagasse is available for energy production (Nguyen Van Song, 2009; Leinonen and Nguyen, 2013).

In this study, the correction factors to make residue quantifications closer to the reality are not discussed. To produce electricity from each kind of biomass, different correction factors need to be added to evaluate for reliable conditions. To make use of the biomass to produce energy for the region, it is necessary to conduct a comprehensive study in technical and economic potentials of each type of biomass sources in generating biomass power energy in the MD.
Currently, the total residual biomass production output in the MD from the considered products account for $40.72 \times$ $10^{6}$ tons, which results in a energy potential of more than $130 \times 10^{6} \mathrm{MWh}$ (around $79.4 \%$ accounts from rice straw, $15.6 \%$ from rice husk, $2.5 \%$ from bagasse and $2.5 \%$ from corn stalk).

According to previous studies, both rice straw and corn stalk in the MD could be used as input materials for the coanaerobic digestion process (Nguyen Vo Chau Ngan, 2012; Nguyen Le Phuong et al., 2015). The produced biogas could be used for power generation. As most biogas digesters in the MD have a very small size of 4 to $20 \mathrm{~m}^{3}$ (Vo Chau Ngan Nguyen, 2011), the production of electricity from the produced biogas is not applicable. In addition, according to suggestions by Leinonen and Nguyen (2013), in order to 
minimize the cost of transportation of livestock waste to biogas digesters while supplying enough waste for electricity generation from biogas, livestock husbandry should be concentrated at a medium or large scale. Thus, to produce electricity from the mentioned biomass sources, there is a need to formulate a novel master plan on Power Generation requiring concentrated livestock production.

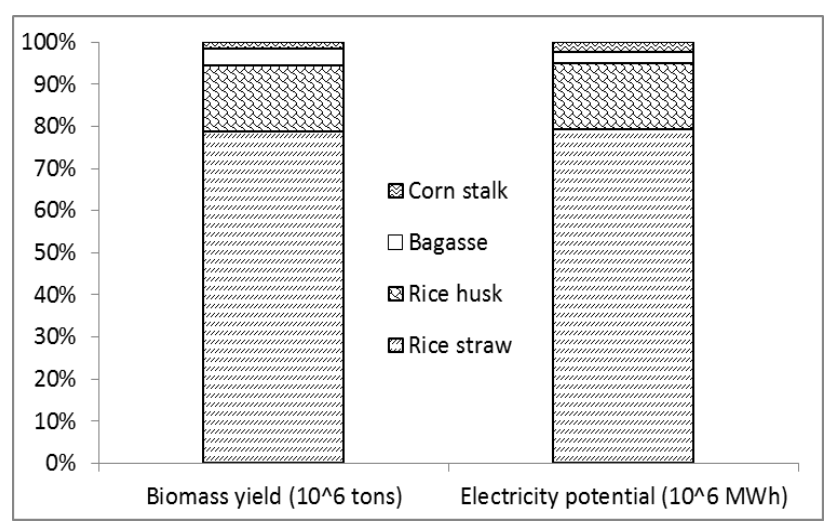

Figure 10. Theoretical potential of electricity production from different biomass sources in the MD in 2020

\section{Conclusions}

Based on the rich biomass sources in the MD, the current total biomass potential for energy production is about 110 million tons (in 2016). The key biomass fuel sources are rice straw (79.35\% of total energy potential) and rice husk (15.63\%). Also, there are available other biomass sources like bagasse $(2.54 \%)$, and corn stalk $(2.48 \%)$. Due to scattered distribution, rice straw is difficult to be collected for centralized power plants but it is normally burnt onfield causing environmental pollution.

There is a need for comprehensive studies on technical and social-economic feasibilities about the efficiency of using these biomass sources in the MD. Biomass energy production could be an optimized solution not only to limit crop residues but also to produce more energy (steam, heating, electricity) for sustainable development in the MD.

Acknowledgement. The authors gratefully acknowledge the financial support of the Project "Sustainable Production of Biogas from Waste Rice Straw" by DANIDA (Code 11-016AU).

\section{References}

[1] Barz M., 2014. Bioenergy and convert fuel. Bioenergy. Summer School on Grid-connected Biomass and Waste-to-Energy Technology and Finance.

[2] GSO - General Statistical Office, 2016. Vietnam yearly statistic 2015. Statistical Publishing House.

[3] Jenjariyakosoln S., Gheewala S. H., Sajjakulnukit B., Garivait S., 2014. Energy and GHG emission reduction potential of power generation from sugarcane residues in Thailand. Energy for Sustainable Development 23: 32-45.

[4] Leinonen A., Nguyen Duc Cuong, 2013. Development of biomass fuel chains in Vietnam. VTT Technology 134.

[5] Ngo Thi Thanh Truc, Duong Van Ni, 2005. Mitigation of Carbon Dioxide emission: An environmental assessment of rice straw burning practice in the Mekong Delta. Proceeding of MEKARN Workshop.

[6] Nhan Pham, 2014. Sugar industry report - Change to survive. Fpt Securities.

[7] NL Agency (2012). Biomass business opportunities Viet Nam. Netherlands Programmes Sustainable Biomass.

[8] Nguyen Le Phuong, Le Thi Thao Quyen, Nguyen Thi Ngoc Huyen, Nguyen Thi Nhu Huynh, Nguyen Thi Diem Trang, Nguyen Vo Chau Ngan, 2015. Biogas production from corn (Zea mays) stalks: Effects of size. Journal of Fisheries Science and Technology of Nha Trang University, Special Issue 69-75.

[9] Nguyen Minh Tung, 2009. Study on produce microorganism fertilizer from bagasse. Technical report. Research Institute of Agricultural Machinery.

[10] Nguyen Ngoc Hoang, 2015. Report on electric power - The message from competition market. Fpt Securities.

[11] Nguyen Van Loc, 2014. Implementing projects on electric co-generation from bagasse in Vietnam - The current issues. Summer School on Grid-connected Biomass and Waste-to-Energy Technology and Finance.

[12] Nguyen Van Song, 2009. Solution for rice husk pollution in the Mekong Delta by clean development mechanism. Journal of Science and Development, Agriculture University of Ha Noi, 7(1): 83-89.

[13] Nguyen Vo Chau Ngan, 2012. Promotion of the biogas plant in the Mekong Delta of Vietnam.

[14] Nguyen Vo Chau Ngan, Tran Sy Nam, 2015. Greenhouse gas emission from on-field straw burning in the Mekong Delta of Viet Nam. Proceeding of 8th Asian crop science association conference. Agricultural University Press. 43-50.

[15] Nguyen Thanh Hoi, 2008. Effects of burying fresh rice straw under submerged soil conditions to rice growing (Oryza sativa L.) in the Mekong Delta. PhD thesis. Can Tho University (in Vietnamese).

[16] Orkide Akgün, Jyrki Luukkanen, 2012. Extension of rice husk gasification technology for electricity generation in Cambodia. Energy Procedia 14: 12441249.

[17] Prime Minister, 2012. Master plan on agricultural production development to 2020, vision to 2030. No. 
124/QĐ-TTg dated on 02/02/2012.

[18] Shafiea S. M., Mahlia T. M. I., Masjukia H. H., Rismanchia B., 2012. Life cycle assessment of electricity generation from rice husk in Malaysia. Energy Procedia 14: 499-504.

[19] Suramaythangkoor T., Gheewala S. H., 2010. Potential alternatives of heat and power technology application using rice straw in Thailand. Applied Energy, 87(1) 128-133.

[20] Tan Hien, 2010. $500 \mathrm{MW}$ electric power yearly from surplus rice husk in the Mekong Delta. Accessed on http://www.vietnamplus.vn/500mw-dien-moi-namtu-trau-thua-o-dbscl/32146.vnp

[21] TTXVN/VIETNAM+, 2016. Sugar cane sector suggest on price adjustment for power generation from bagasse. Accessed on http://www.vietnamplus. vn/nganh-mia-duong-kien-nghi-dieu-chinh-gia-diendong-phat-tu-ba-mia/420214.vnp

[22] Vo Chau Ngan Nguyen, 2011. Small-scale anaerobic digesters in Vietnam - development and challenges. Journal of Vietnamese Environment, 1(1): 12-18. 